\title{
Giant salamander from the Miocene of the Mecsek mountains (Pécs-Danitzpuszta, southwestern Hungary)
}

\author{
Zoltán Szentesi $^{1} \cdot$ Krisztina Sebe $^{2}$ (D) Márton Szabó ${ }^{1,3}$
}

Received: 29 May 2019 / Accepted: 24 October 2019 / Published online: 12 December 2019

(c) The Author(s) 2019

\begin{abstract}
The Late Miocene fossil locality Pécs-Danitzpuszta (Mecsek Mts., Hungary) has yielded cranial and postcranial bones of giant salamanders. Based on taxonomical studies, these relatively well-preserved, isolated bones belong to the cryptobranchid species Andrias scheuchzeri. Whereas the species is well documented from Neogene of Central Europe, this is the first record of the genus Andrias from Hungary, representing the sole record of giant salamanders from the country. The fossils were found in Upper Miocene sands deposited in the brackish Lake Pannon, but their late Miocene age is uncertain, because they occur together with vertebrate remains reworked from older sediments. The mild and humid climate and the presence of freshwater wetlands on the mainland indicated by the fossil flora, the syn-depositional uplift of the mountains providing for a rugged topography, and the intense clastic sediment input into Lake Pannon indicative of a fluvial network on the Mecsek Island and of sufficient precipitation support that conditions were convenient for the giant salamanders in the early late Miocene. Together with three other late Miocene localities in Austria, the Pécs-Danitzpuszta site is the fourth Miocene occurrence of Andrias in the Pannonian Basin System. It resembles the first three localities in lying at the foot of elevated terrain and in having freshwater input, conditions thought to be necessary for giant salamander habitats.
\end{abstract}

Keywords Amphibia $\cdot$ Andrias $\cdot$ Palaeoclimate $\cdot$ Palaeoenvironment $\cdot$ Topography

\section{Introduction}

Cryptobranchids are giant salamanders which can reach over $1.5 \mathrm{~m}$ in their total length. The fossil evidence in Asia and North America suggest that the evolutionary history of Cryptobranchidae extends back to Paleocene (Naylor 1981;

Handling Editor: Jörg Fröbisch.

Krisztina Sebe

sebe@gamma.ttk.pte.hu

Zoltán Szentesi

szentesi.zoltan@nhmus.hu

Márton Szabó

szabo.marton.pisces@gmail.com

1 Department of Paleontology and Geology, Hungarian Natural History Museum, Pf. 137, 1088 Budapest, Hungary

2 Department of Geology and Meteorology, University of Pécs, Ifjúság ú. 6, 7624 Pécs, Hungary

3 ELTE Post-Lendület Dinosaur Research Group, Department of Palaeontology, Eötvös Loránd University, Pázmány Péter sétány 1/C, 1117 Budapest, Hungary
Vasilyan and Böhme 2012), with their fossils being known later from Europe, Asia and North America (Browne et al. 2012). The recent species of this family (Cryptobranchus alleganiensis, Andrias davidianus and A. japonicus) range over the cool temperate zones of China, Japan and North America. Within these distribution zones the animals generally prefer clear, oligotrophic streams and rivers with rocky bed and steep banks (e.g. Cundall et al. 1987; Nickerson et al. 2003; Okada et al. 2008; Dai et al. 2010; Browne et al. 2013). In contrast, late Oligocene to late Pliocene representatives of Andrias occurred in large ponds or lakes as well. Their fossils were unearthed at vertebrate sites of Germany: Upper Oligocene of Rott, Middle Miocene of Öhningen, Middle and Upper Miocene of Wartenberg, Upper Miocene of Reisenburg and Upper Pliocene of Willershausen; of the Czech Republik: Lower Miocene of Břeštany; and of Austria: Upper Miocene of Götzendorf, Brunn-Vösendorf and Mataschen (Papp et al. 1953; Thenius 1954; Meszoely 1966; Westphal 1970; Böttcher 1987; Miklas 2002; Tempfer 2004; Böhme et al. 2012). All European Miocene findings of giant salamanders belong to the species Andrias scheuchzeri (Westphal 1958; Roček 1997; Tempfer 2004). 
Though in Europe Cryptobranchidae showed highest abundance in the Miocene and the fossils of Andrias are well known from the Upper Miocene of the Vienna Basin as mentioned above, so far no remains had been known from the Miocene of Hungary. In 2016 a Hungarian National Research, Development and Innovation Office project (PD104937) allowed us to transfer a considerable private collection of Miocene vertebrate fossils to the public institutional collection of the University of Pécs. This material contained cryptobranchid remains from a sand pit in the Mecsek Mountains, SW Hungary. The recognition of these fossils lead us to survey all available collections from this area, and the search revealed several further salamander bones, all from the same locality, the Pécs-Danitzpuszta sand pit. Here we describe these remains and discuss their stratigraphic and palaeogeographic significance.

\section{Geological setting}

The Pécs-Danitzpuszta sand pit lies in SW Hungary, on the SE margin of the Mecsek Mountains, at the eastern boundary of the city of Pécs (Fig. 1) and exposes deposits of the late Miocene (Pannonian) Lake Pannon (Kleb 1973). This brackish lake evolved from the Central Paratethys and existed throughout the late Miocene and the early Pliocene, from 11.6 to 4.5 Ma (Magyar et al. 1999).

In the Danitzpuszta sand pit two different types of lacustrine deposits are exposed. The succession is heavily deformed due to intra- and post-Pannonian movements, thus the boundary between the two rock types is vertical (Fig. 1c), and younging is both towards the south and upwards. The older deposits are greyish white calcareous marls, exposed in (sub)vertical layers in the northern wall of the sand pit. Stratigraphically they belong to the Tótkomlós Calcareous marl Member of the sublittoral, open-water Endrőd Formation. They show a relatively sharp but conformable boundary with the overlying sands.
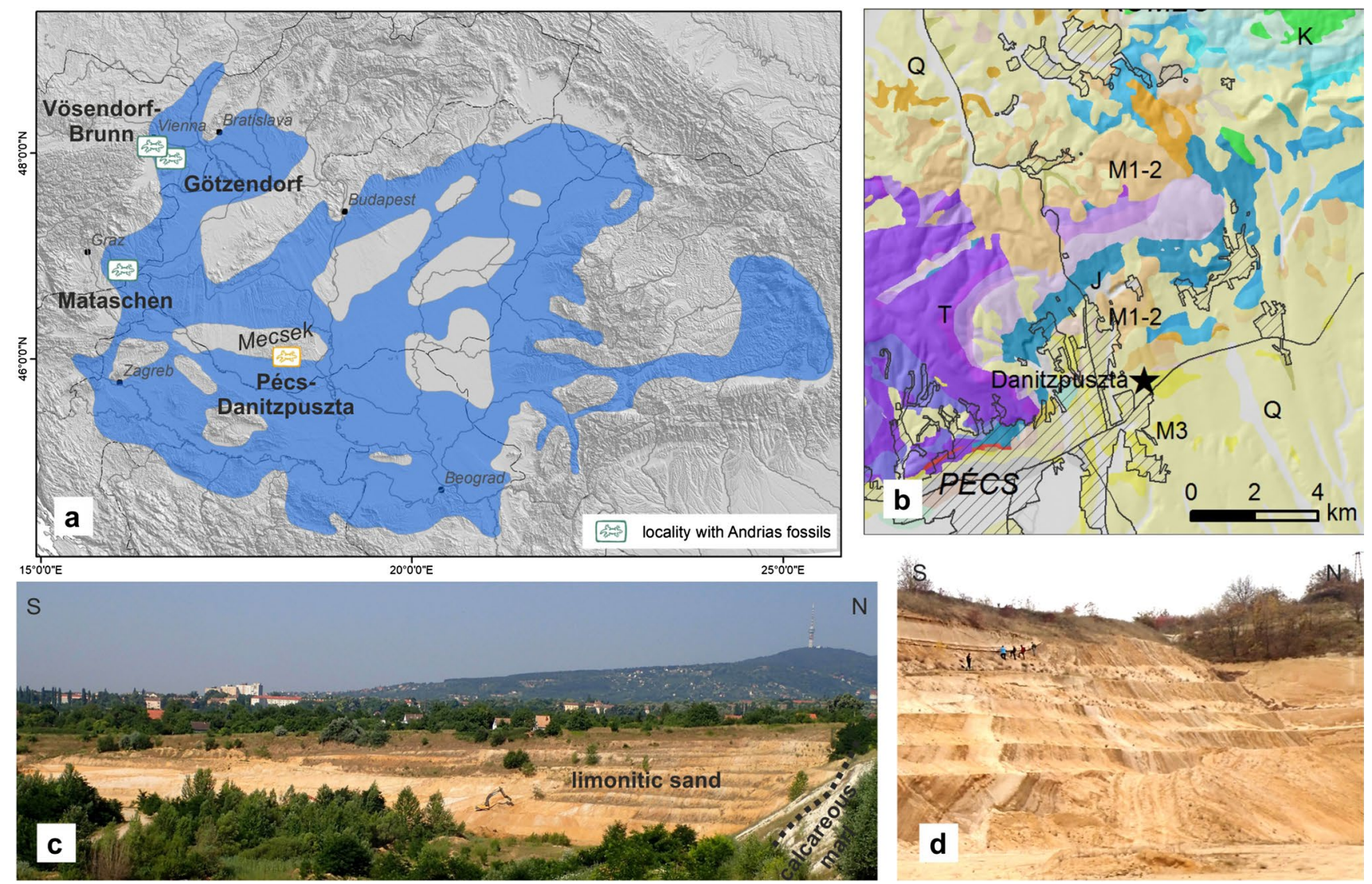

Fig. 1 Geological setting of the Pécs-Danitzpuszta sand pit. a Location of the site, with published Miocene fossil sites with Andrias scheuchzeri in the Pannonian Basin. Blue patch indicates the extent of Lake Pannon around the time of sediment accumulation at Danitzpuszta ( 9.5 Ma; after Magyar et al. 1999). b Simplified geologi- cal map of the area. Legend: T: Triassic; J: Jurassic; K: Cretaceous; M1-2: Lower-Middle Miocene; M3: Upper Miocene; Q: Quaternary rocks. $\mathbf{c}$ Panorama of the western wall of the sand pit. Bagger in centre for scale. d Steeply dipping limonitic sands in the northern part of Fig. c. Note people for scale 
Based on the mollusc association belonging to the Lymnocardium schedelianum sublittoral mollusc biozone of Lake Pannon (sensu Magyar and Geary 2012), these marl beds can be dated to 11-10 Ma (Magyar in Sebe et al. 2015a). The younger sediments are limonitic, yellow, coarse-grained, gravelly sands, now exposed in the long western wall of the sand pit, which were worked by the mine during the time it was active. The sands were derived from the denudation of the older Miocene and basement rocks of the mountains and are classified into the Kálla Formation. Within the sands, bedding dip gradually decreases upwards and towards the south, pointing to ongoing tectonic activity - uplift of the mountains - during sedimentation (Konrád and Sebe 2010). The mollusc assemblage found in the sands suggests an age of 9.5-10.0 Ma for this deposit (Magyar in Sebe et al. 2015a).

The sand pit is a famous vertebrate locality in the region because of the large number of fossils found in the limonitic sands. Remains are dominated by fish (bony fish, shark, ray), reptile (mostly turtle) and various aquatic and terrestrial mammal remains (Kazár et al. 2007; Konrád et al. 2010; Sebe et al. 2015a). A considerable portion of them, e.g. those of euhaline taxa, must have been reworked from slightly older sediments of Badenian and Sarmatian s.s. (Langhian and Serravallian) age. However, partially articulated skeletons have also been found in the sand pit, which indicate that at least some of the fossils belonged to animals which lived during the accumulation of the exposed sediments. Cryptobranchidae fossils were collected in the described vertebrate-bearing limonitic sands (centre of the western wall: $46^{\circ} 6^{\prime} 1.86^{\prime \prime} \mathrm{N}, 18^{\circ} 16^{\prime} 56.56^{\prime \prime} \mathrm{E}$ ) by multiple collectors between 2006 and 2018 .

\section{Materials and methods}

The investigated Andrias fossils from the locality of PécsDanitzpuszta are deposited in three collections:

- University of Pécs, collection of the Department of Geology and Meteorology; the bones were collected by the amateur collector Tamás Németh.

- Collection of the Mining and Geological Survey of Hungary; the fossils were collected by the amateur collector Ferenc Cserpák.

- Collection of the József Attila City Library and Museum (Komló); this material was collected by the amateur collector László Kanizsai.

These aforementioned collections contain two left and two right maxillae, eight left and eight right dentaries, four atlases, three trunk vertebrae, one left ilium and one left femur. All specimens are incomplete and have yellowish brown colour.
Other collections screened but devoid of salamander fossils were that of the Hungarian Natural History Museum and those of numerous private collectors known to include Miocene vertebrate remains from the Mecsek Mts.

The previous descriptions of the specimens of the wellknown species $A$. scheuchzeri are referenced in the synonym list. The anatomical nomenclature in the systematic part follows Meszoely (1966), Miklas (2002), Ratnikov and Litvinchuk (2009), Gardner et al. (2010), Vasilyan and Böhme (2012), and Vasilyan et al. (2013).

Anatomical terms. AL: distance between the cranial edge of two condyli occipitales and the caudal end of the vertebral center; $\mathrm{AB}$ : distance between the lateral margins of both condyli occipitales; CTH: cotyle height; CTW: cotyle width; PO: distance between the cranial edges of the condyli occipitales and the cranial edge of the processus odontoideus.

Abbreviations. PTE: University of Pécs, collection of the Department of Geology and Meteorology; MBFSZ: Mining and Geological Survey of Hungary; JAM: József Attila City Library and Museum Collection.

\section{Systematic paleontology}

Class Amphibia Linnaeus, 1758

Subclass Lissamphibia Haeckel, 1866

Order Caudata Scopoli, 1777

Suborder Cryptobranchoidea Dunn, 1922

Clade Pancryptobrancha Vasilyan, Böhme, Chkhivadze, Semenov and Joyce, 2013

Family Cryptobranchidae Fitzinger, 1826

Genus Andrias von Tschudi, 1837

Andrias scheuchzeri (Holl, 1831)

Figures 2, 3, 4, 5, 6, 7

1966 Andrias scheuchzeri-Meszoely: 499.

1970 Andrias scheuchzeri (Holl, 1831)—Westphal: 253, fig. 1a-e.

1987 Andrias scheuchzeri-Böttcher: figs. 2a-d, 4a-c, 5a-d, 9a-d, 11a-d, 12a-d.

2002 Andrias scheuchzeri Holl, 1831-Miklas: 168, pl. 1, fig. 4.

2004 Andrias scheuchzeri Holl, 1831-Tempfer: 258, pl. 1, figs. 1-2.

2013 Andrias scheuchzeri-Vasilyan et al.: fig. 3a-c.

Material examined. Two left (MBFSZ V.2019.99.1., PTE -5152) and two right fragmentary maxillae (MBFSZ V.2019.97.1., 98.1.); eight left (MBFSZ 

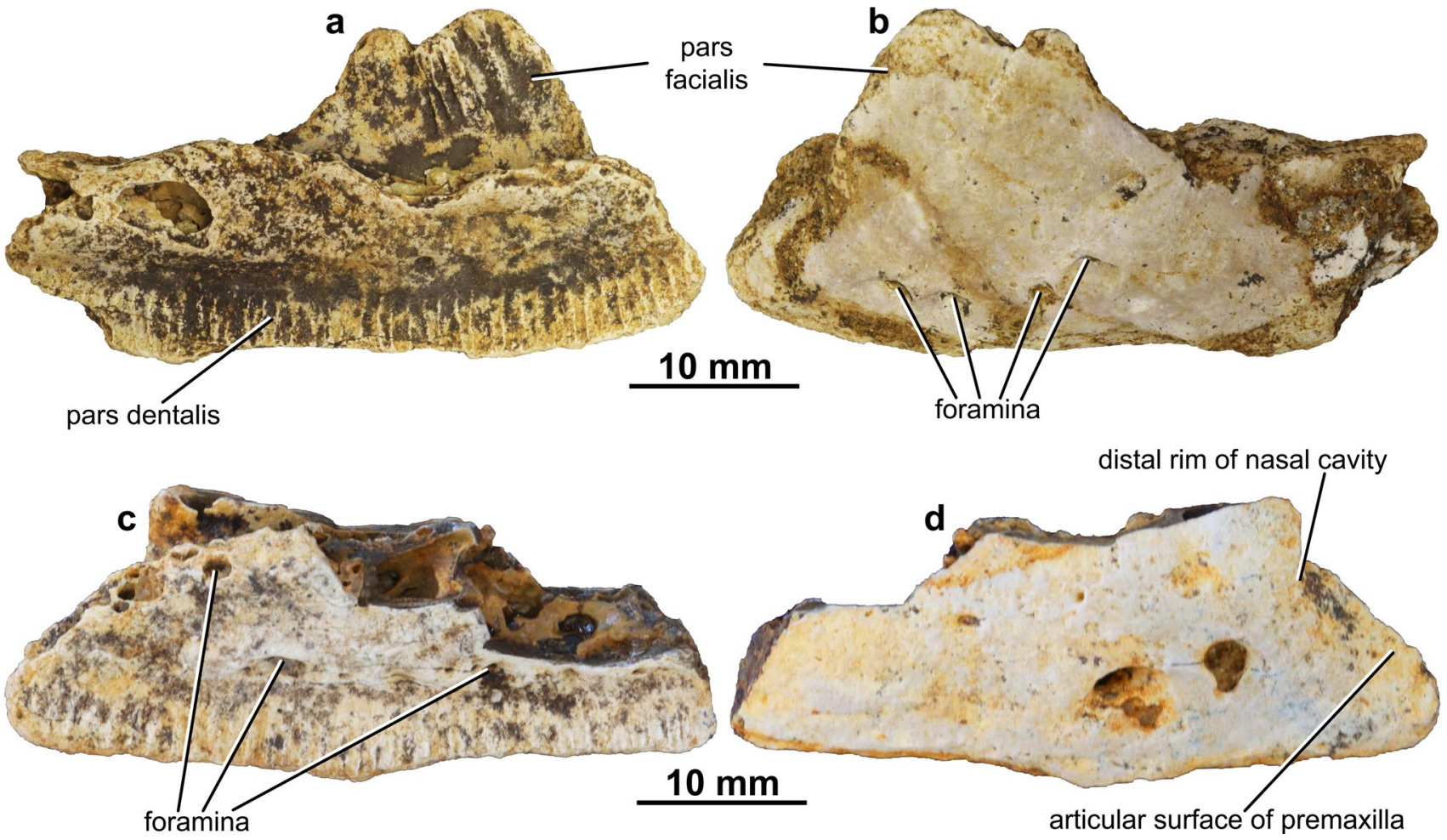

Fig. 2 Maxillae of Andrias scheuchzeri from Pécs-Danitzpuszta. Left maxilla (a, b; PTE-5152), right maxilla (c, d; MBFSZ V.2019.97.1.). a, c: ventromedial view; $\mathbf{b}, \mathbf{d}$; dorsal view
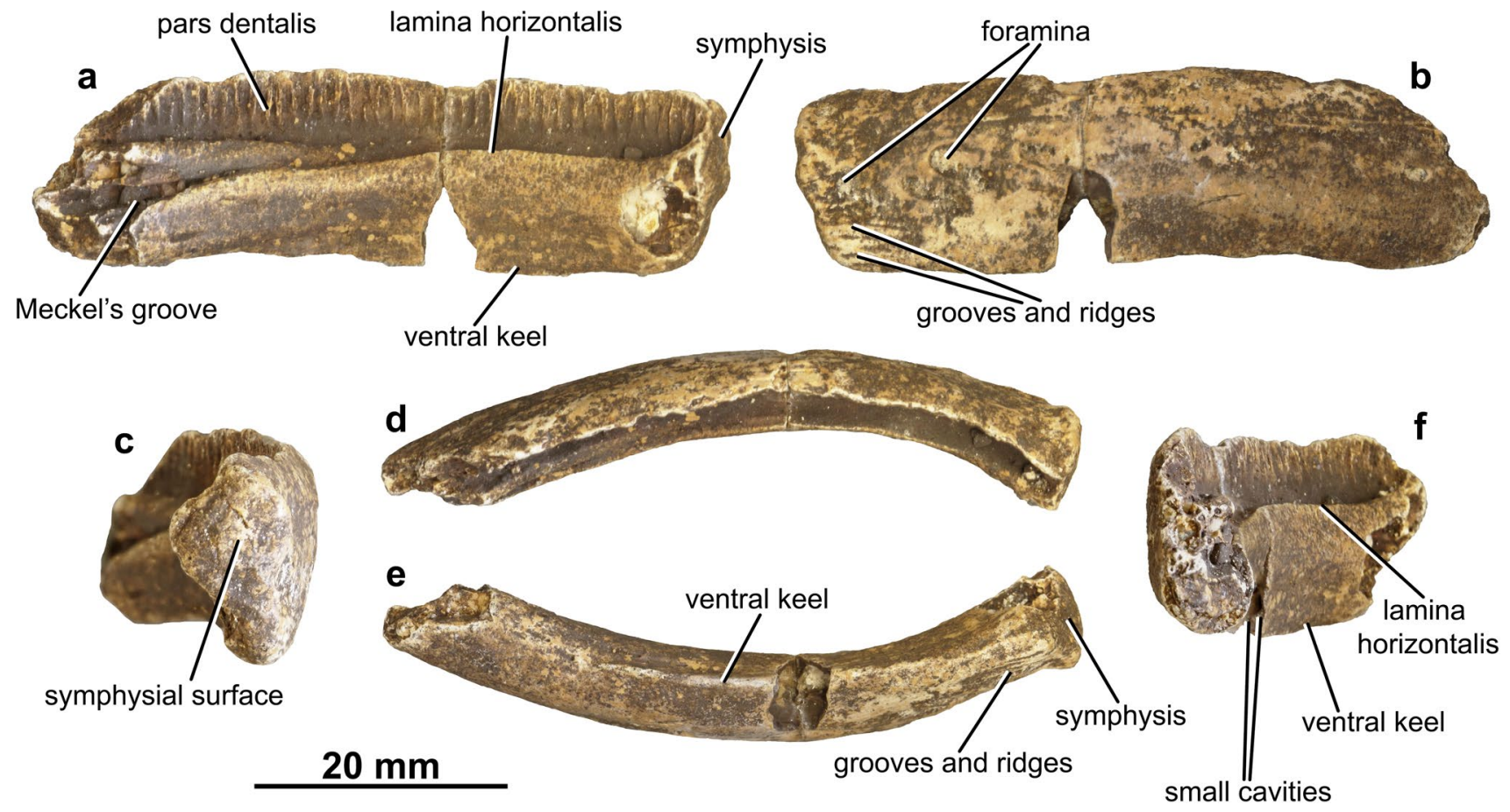

Fig. 3 Left dentary of Andrias scheuchzeri (a-f; PTE-5148) from Pécs-Danitzpuszta. a: lingual view; b: labial view; c: medial view; d: dorsal view; e: ventral view; f: medial view 
Fig. 4 Dentaries of Andrias scheuchzeri from Pécs-Danitzpuszta. Right dentaries: a, b; JAM T/2019.4.1., c: MBFSZ V.2019.100.1., d: MBFSZ V.2019.101.1., h: MBFSZ V.2019.110.1.; left dentaries: e: MBFSZ V.2019.103.1., f: MBFSZ V.2019.107.1., g: MBFSZ V.2019.108.1.. a, c-h: lingual view; b: posterior view
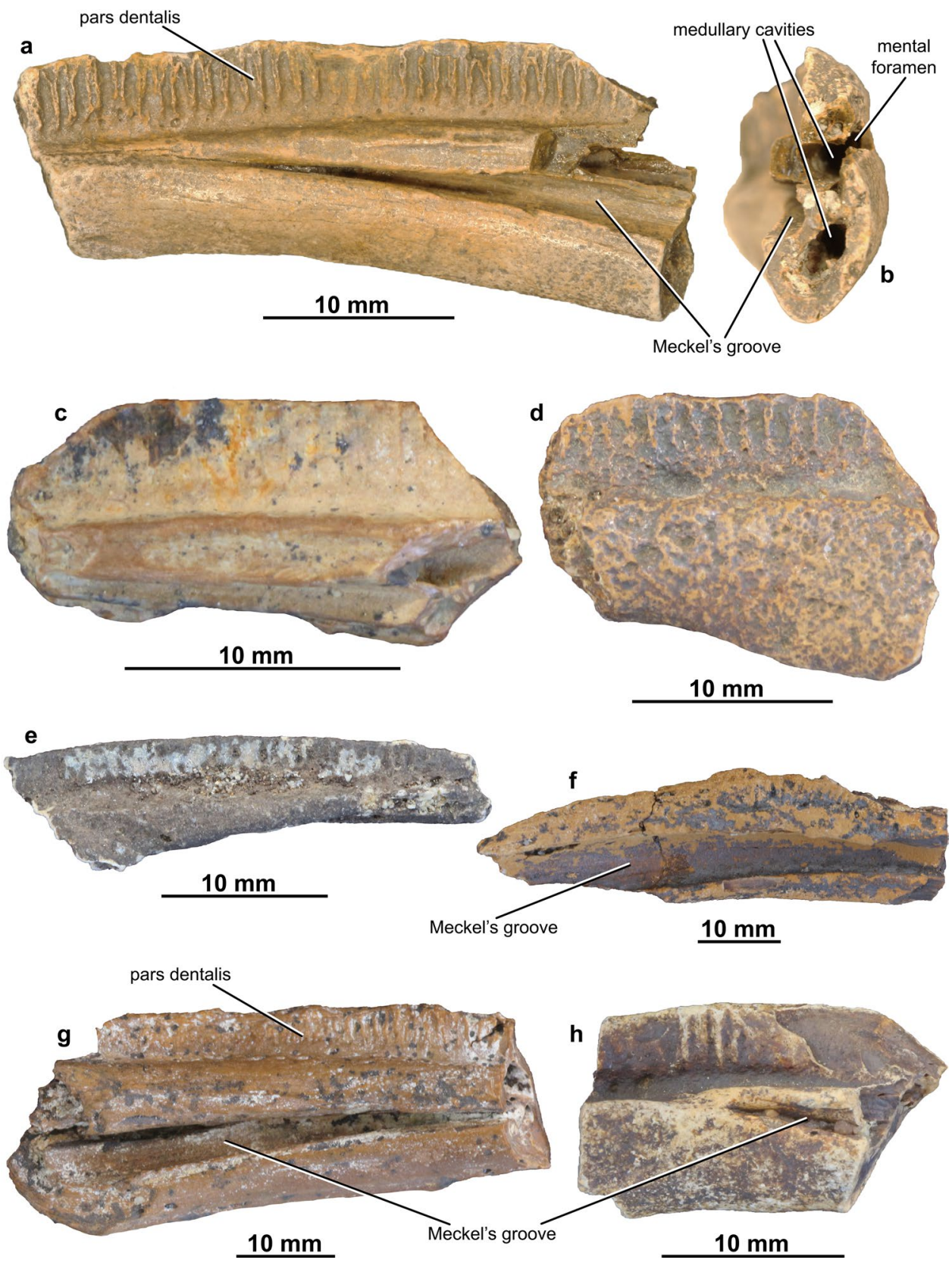

V.2019.103.1.105.1., 106.1., 107.1., 108.1., 109.1., PTE5148-5151, JAM 2015.10.1) and eight right dentaries (MBFSZ V.2019.100.1., 101.1., 102.1., 104.1., 110.1., JAM 2006.217.155, 2008.537.1, T/2019.4.1.); four fragmentary atlases (JAM 2006.236.96, MBFSZ V.2019.111.1., 113.1., 114.1.); three fragmentary trunk vertebrae (JAM T/2019.2.1., 3.1., MBFSZ V.2019.112.1.), one left ilium (JAM 2006.185.47) and one left femur (JAM T/2019.1.1.).
Description.

Maxilla-Only the anterior portion of the bone is preserved with the partially preserved pars facialis (PTE-5152, Fig. 2a, b). The labial surface of four maxillae (PTE-5152, MBFSZ V.2019.99.1., 97.1., 98.1.) is covered by rough ridges and pierced by four foramina below the base and by one foramen on the posterior part of pars facialis. On the best preserved maxilla (PTE-5152), the pars facialis is located close to the anterior extremity. The length of the bone is $21 \mathrm{~mm}$. The 
Fig. 5 Atlases of Andrias scheuchzeri from Pécs-

Danitzpuszta. a-c: JAM 2006.236.93., d, E: MBFSZ V.2019.111.1. a, d: ventral view; b, e: anterior view; c: posterior view

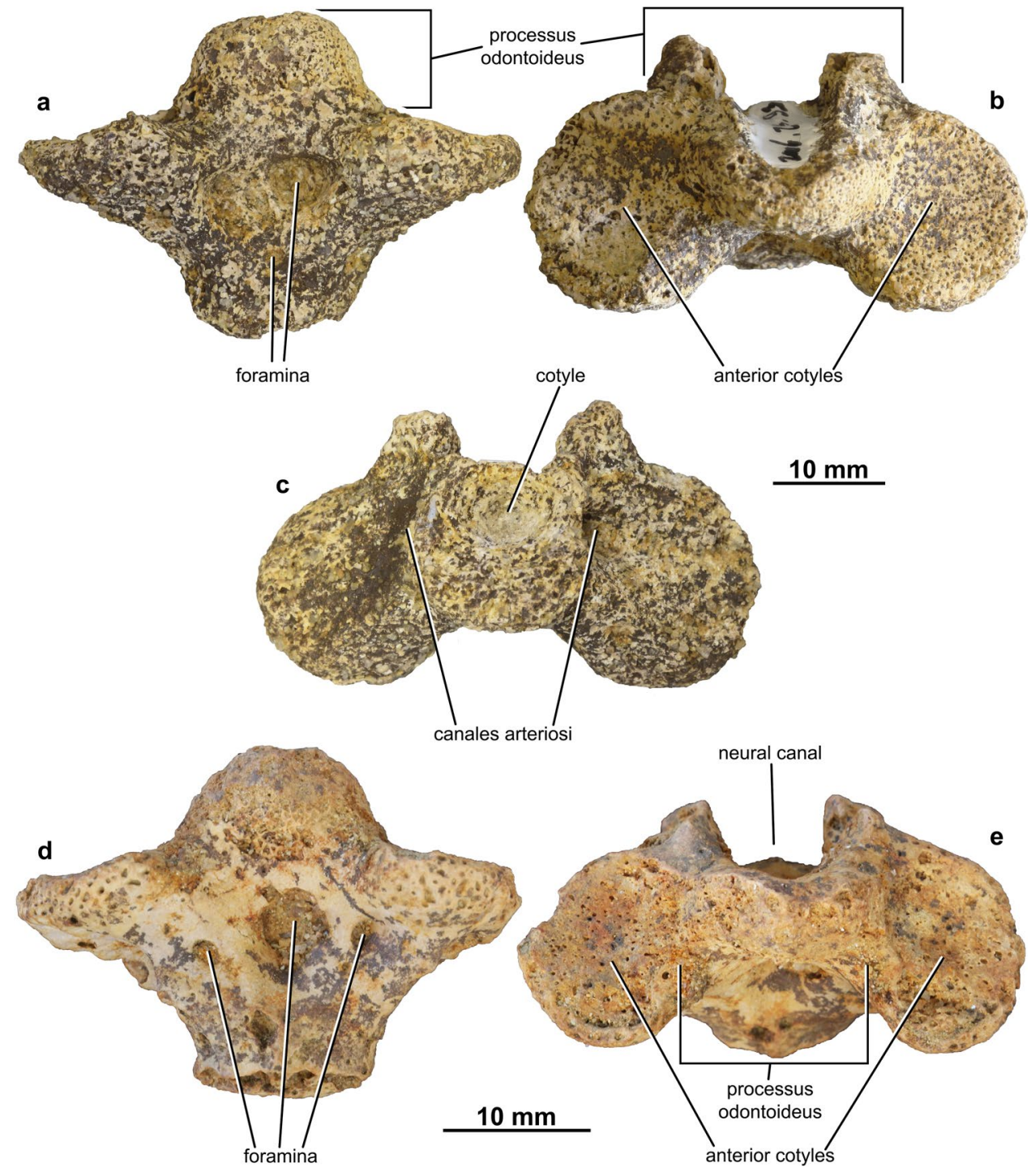

anterior edge is almost straight, whereas the posterior edge is damaged, and it was possibly concave. The labial surface bears few larger and smaller foramina, which pierce the bony tissue and extend towards the pars palatina. The anterior part of the maxilla formed the distal edge of the nasal cavity (see specimen MBFSZ V.2019.97.1., Fig. 2d) and below this the articular surface is visible, which is overlapping the premaxilla. The pars palatina extends medially from the base of the pars facialis. Its medial margin is broken in specimen MBFSZ V.2019.97.1., its ventral part is smooth, and bears a rounded foramen about at the base of the tooth plate and possibly two other on the damaged posterior part. Only the tooth pedicels are preserved on the pars dentalis, but the preserved portions of the tooth plate show that the maxilla was provided with tightly located and narrow teeth, similar to the dentaries. The ventral edge of the pars dentalis is damaged and abraded.
Dentary - The dentaries are elongated, high, curved and anteriorly thickening also bones, which are strongly flattened labiolingually (Figs. 3, 4). All specimens are damaged; the anteroposterior length of the specimens varies between 20 and $60 \mathrm{~mm}$. Near the symphysis, the height of the dentaries ranges between 5 and $18 \mathrm{~mm}$. The depth of the pars dentalis is less than half of the depth of the corpus dentalis.

In one of the specimens (PTE-5148, Fig. 3), the symphysis is relatively well preserved, only the ventrolingual part is missing. Medially, the symphyseal surface is strongly rugose. Both lingually and labially, a well-developed ridge is noticeable on the symphyseal surface, which projects from the level of the pars palatina to about the half of the height of the dentary. This ridge separates two pads of elastic cartilage within the (inter)mandibular joint, which enables high mobility of the mandibular symphysis in giant salamanders (Cundall et al. 1987). 
Fig. 6 Trunk vertebrae of Andrias scheuchzeri from Pécs-Danitzpuszta. a-d: JAM T/2019.2.1., e.g. JAM T/2019.3.1. a: left lateral view; $\mathbf{b}, \mathbf{f}$ : anterior view; $\mathbf{c}, \mathbf{g}$ : ventral view; d: posterior view; e: right lateral view
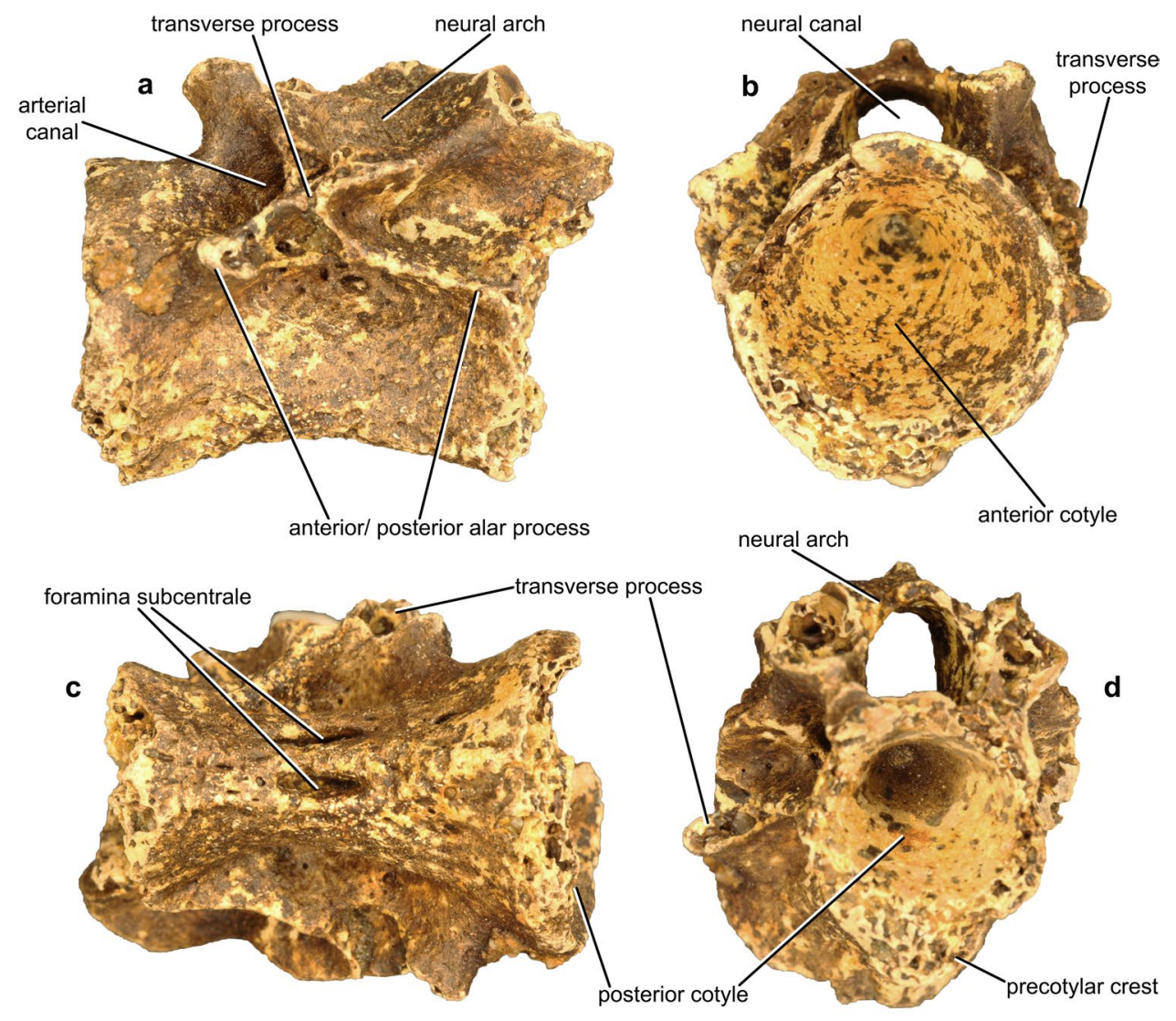

$10 \mathrm{~mm}$

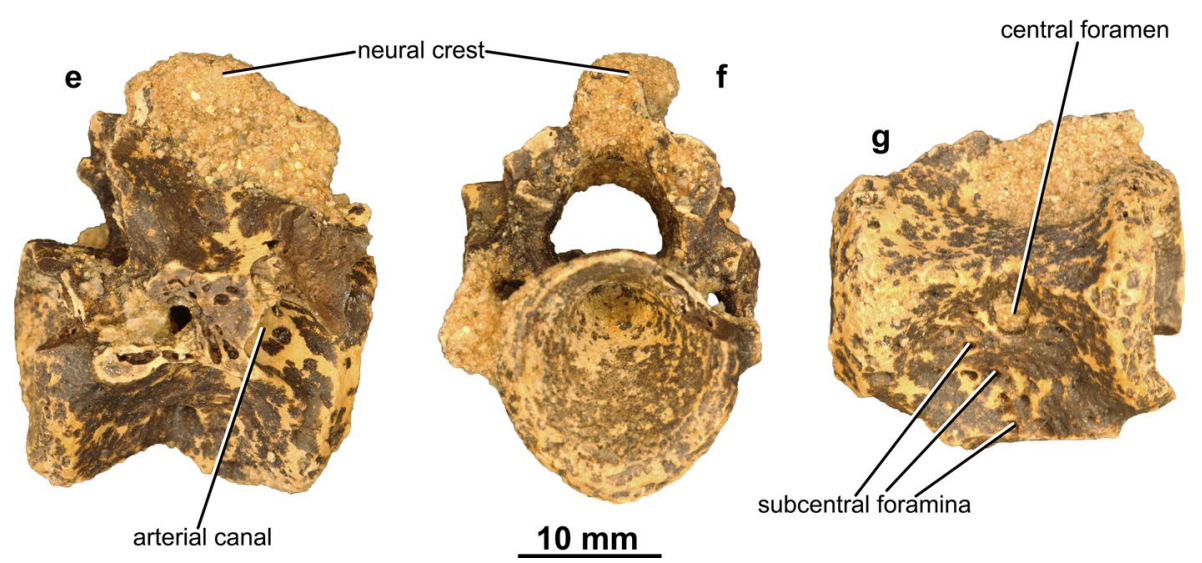

The subdental shelf is flat anteriorly and becomes shallow at the middle part of the bone. The posterior part is missing on all studied dentaries. The surface of the subdental shelf displays irregularly placed small foramina and pits, which might lead through the compact bone into the medullary cavity. The most anterior foramina might be connected to the symphysis (PTE-5148, Fig. 3b). The anterior part of the lamina horizontalis is angular up to the anterior end of the Meckel's groove, and from this point it becomes rounded towards the anterior tip of the bone. In some dentaries the Meckel's groove extends to the height of the lamina 
Fig. 7 Left ilium (a-c: JAM 2006.185.47.) and left femur (d-f: JAM T/2019.1.1.) of Andrias scheuchzeri from PécsDanitzpuszta. a: lateral view; a: medial; c: ventral view; d: dorsal view; e: ventral view; $\mathbf{f}$ : posterior view

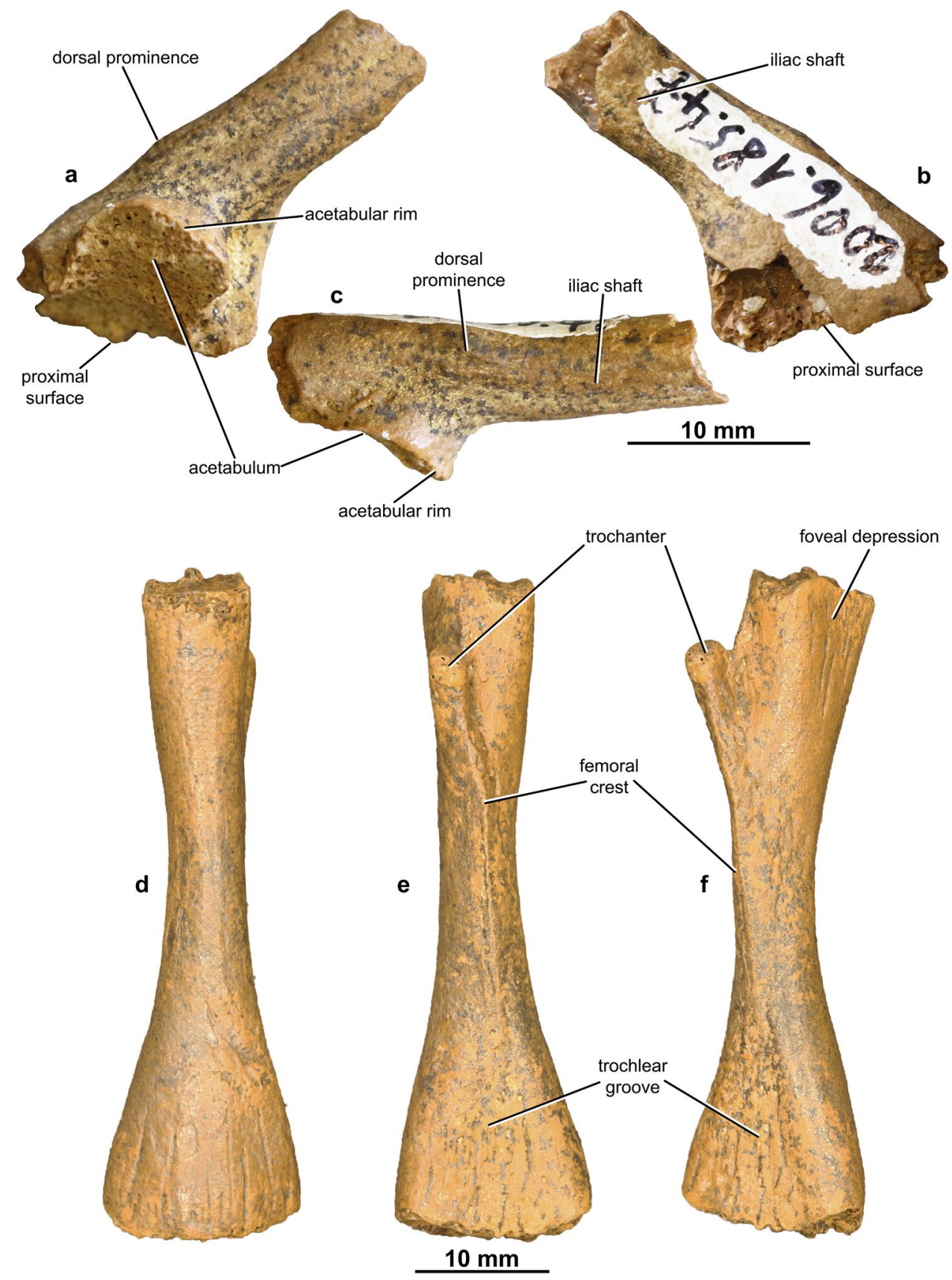

horizontalis, intermitting it and connecting it to the subdental shelf (e.g. PTE-5148, Fig. 3a).

The lingual surface of the corpus dentalis is smooth; only some small foramina are present. In cross-section, the corpus dentalis is broader dorsally than ventrally (Figs. 3f, 4b). The ventral keel is only anteriorly angular and becomes rounded from a just behind anterior end of the Meckel's groove. In cross-section view, it is completely rounded on its posterior part or, in some dentaries, it also could be flattened (e.g. PTE-5148, Fig. 3e). The Meckel's groove is a dorsoventrally slightly curved cuneiform, which significantly broadens posteroventrally.
Labially, the eminentia longitudinalis extends from the longitudinal axis. Behind the symphysis the labial surface of the bone is covered by longitudinal grooves and ridges. This area was an adhesional part of the superficial symphyseal ligament of the mandibular joint (Cundall et al. 1987). The labial surface of the dentary possesses mental foramina arranged according to the anteroposterior axis of the bone slightly above the bone midline. Posteriorly, these foramina decrease both in size and number (Fig. 3b).

The dentary is relatively well ossified; the cortex is thick in cross-section. In the corpus dentalis, the two largest medullary cavities are comparatively small, surrounded by 
significantly smaller cavities. The largest medullary cavity appears superficially; it grows towards the posterior part of the bone. The ventral keel may possess some small medullary cavities in the anterior portion of the dentary (Fig. 3f). The entire medullary cavity system of the dentary is not closed; these cavities are in contact with the bone surface through the mental foramina. It is well discernible on the available cross-sections that the compactness of the bone changes along the dentary on is anteroposterior axis (see Fig. 4b).

Atlas-The atlases (Fig. 5) are amphicoelous; all specimens lack the neural arch. The vertebral body of the largest specimen (JAM 2006.236.96.) has a length of $A L=28 \mathrm{~mm}$ and a width of $\mathrm{AB}=48 \mathrm{~mm}$, while the smallest (MBFSZ V.2019.113.1.) is $A L=21 \mathrm{~mm}$ long and $A B=34 \mathrm{~mm}$ wide. The condyli occipitales are large; the processus odontoideus (tuberculum interglenoideum sensu Estes 1981) is dorsally notched and is continuous with the anterior cotyles with connection to the cranial articular surfaces. The value of $\mathrm{PO}=16 \mathrm{~mm}$ (on the smallest atlas $\mathrm{PO}=12 \mathrm{~mm}$ ) which builds up the third of the total length of this ventral part of the atlas. The posterior cotyle is large and concave. It is ventrally thickened, CTW $=22 \mathrm{~mm}$ and $\mathrm{CTH}=13 \mathrm{~mm}$ on the largest atlas (JAM 2006.236.96), while CTW $=12 \mathrm{~mm}$ on the smallest specimen (MBFSZ V.2019.113.1.). The "canales arteriosi, ramulos spinales ad medullam admittentes" (according to Westphal 1958, p. 31) opens laterally. These canals proceed obliquely upwards in the vertebral body, while these canals are perpendicular to the vertebral body in ventral view. The largest foramen on the ventral side of the atlas is situated about at the middle of the bone, surrounded by smaller foramina.

Trunk vertebrae-The trunk vertebrae are large and massive, but all of them are incomplete (Fig. 6a-g). The centrum of the largest specimen (JAM T/2019.3.1., Fig. 6e-g) measures $31 \mathrm{~mm}$, while that of the two smallest is $27 \mathrm{~mm}$ (JAM T/2019.2.1. Fig. 6a-d and MBFSZ V.2019.112.1. (not figured). The convex centrum has a sand glass-like outline in lateral view. Its middle part is narrow. It widens towards the cotyles, forming perycotylar crests. The centra are deeply amphicoelous and circular in all specimens. A large central foramen is situated at the ventral midline of the centrum (Fig. 6c). The cotylus has a porous surface.

The subcentral surface of the centrum is rough. It bears a large and several smaller foramina. The central foramen penetrates the bony tissue on the midline of the ventral side, but in the specimen JAMS T/2019.3.1, it is located ventrolaterally on the centrum (Fig. 6g). The shape of the central foramina varies between oval and rounded.

The neural canal is wide and dorsoventrally depressed. The surface of the neural arch is relatively smooth; it bears a neural crest. This crest (see specimen JAM T/2019.3.1., Fig. $6 \mathrm{e}-\mathrm{g}$ ) is short, laterally flattened but relatively thick. Its dorsal edge is incomplete; its anterior edge is vertical, while the posterior is pointing backwards. In anterior view, the neural crest widens dorsally. The posterior portion of the neural arch is missing in all specimens. Both the pre- and postzygapophyses and transverse processes are broken.

Between the medial surfaces of the transverse process and the vertebral centrum an enlarged arterial canal (Fig. 6a, e) for the arteria vertebralis (after Francis 1934) is visible.

Ilium-The partially preserved left ilium JAM 2006.185.47 (Fig. 7a-c) is the only specimen which can be classified as a salamandrid ilium from the fossil site of Pécs-Danitzpuszta. The total length of this bone fragment is $25 \mathrm{~mm}$, its height is $12 \mathrm{~mm}$.

The ilium of urodeles, despite their similar structure to that of the anuran ilium, has a fundamental difference in the position of iliac shaft in living amphibians. Compared to the anterodorsally projected anuran iliac shaft, the iliac shaft of urodeles projects slightly more posterodorsally, with $90^{\circ}$ difference. Unfortunately, this distinction is difficult to recognize in isolated ilia (Reese 1906; Gardner et al. 2010) like this one. This description follows instructions of Gardner et al. (2010).

The iliac shaft is rod-like; its surface is smooth, and it has a well-developed groove extending from the acetabular region towards posterodorsally on the anterolateral side. Anteroventrally, the iliac shaft wears a posterodorsally extending, rounded depression, while the ventral part of the bone is also smooth and convex. In cross-section, this part of the bone shows slightly triangular outline with rounded vertices. The acetabulum is large; it has a well-developed acetabular rim, which projects strongly laterodorsally. The iliac shaft bears a slightly prominent tuberosity, which is situated anterodorsally from the acetabulum. The preacetabular region has an oval preacetabular fossa. The supraacetabular region is relatively high and plate-like, while the subacetabular portion is relatively low and wide (Fig. 7c). In posteroventral view, the acetabular part is very wide; the articulation of pubis on the proximal surface (= pubo-ischiadic plate) is crescent-like, whilst the articulation part of the ischium is damaged.

Up to the present study, no ilium of Andrias scheuchzeri has been described; even the holotype lacks this part of the skeleton (Holl 1831). Based on the aforementioned morphology, the presented bone definitely belongs to a salamander (e.g. Gardner et al. 2010). The size of the ilium fits the verifiable Andrias scheuchzeri remains recovered at this site, so this specimen can be referred to this species.

Femur-This is an elongated long bone JAM T/2019.1.1. Figure $7 \mathrm{~d}-\mathrm{f}$, which widens toward its epiphyses. The surface 
of this specimen is rough; it is ornamented with pits and grooves, especially the dorsal part of its distal extremity. The proximal epiphysis is broken; the distal one is rounded, dorsally convex, and ventrally concave with a triangularshaped depression. The trochanter crest is thorn-like and rounded in cross-section. The femoral crest is sharp and slightly S-shaped in ventral view.

Remarks. The above described specimens share several characteristics with all crown cryptobranchids: large body size; massive bones; bilateral asymmetric kinetics of the lower jaw; trochanter fused with the proximal head of the femur (e.g. Westphal 1958; Meszoely 1966; Cundall et al. 1987; Vasilyan and Böhme 2012; Vasilyan et al. 2013). The rough inner surface of pars facialis (with ridges and depressions), the strong curvature of dentaries (e.g. Westphal 1958; Meszoely 1966; Tempfer 2004) and the arrangement and features of the teeth (e.g. Greven and Clemen 1980) are characters typical for Andrias. The strongly curved maxillae with narrow and long teeth pedicels; the well-ossified, strongly curved dentaries with thick cortex, the mediumsized medullary cavities surrounded with smaller cavities; the amphicoelous atlas with large processus odontoideus and a larger central foramen among several small foramina ventrally; the dumbbell-shaped, amphicoelous trunk vertebrae with short neural spine suggest these fossils belong to species Andrias scheuchzeri (e.g. Westphal 1958; Estes 1981; Vasilyan et al. 2013.) The anatomical features of the ilium are the same as urodeles (see Gardner et al. 2010), while the size of this bone suggests that this bone also belongs to the species Andrias scheuchzeri.

The robust, strongly curved, low maxilla differs from that of Andrias matthewi. The densely situated, high tooth pedicels of the maxillae and the strongly curved dentaries with deep sulcus dentalis also relate these specimens to A. scheuchzeri (see Estes 1981). The dentary differs from Ukrainasurus hypsognatus and Andrias davidianus in its more robust structure of the corpus dentalis. It is less robust labiolingually in cross-section than the Zaissaurus beliajevae (Vasilyan et al. 2013: 306, fig. 3b-e) and the Aviturus exsecratus (see Vasilyan and Böhme 2012: 3, fig. 4a-c). In cross-section view, the bone tissue of the dentary differs from that of A. davidianus and Ukrainasurus hypsognatus in the thick cortical bone and the significantly smaller cavities, from that of the Zaissaurus beliajevae in more numerous and denser medullary cavities (see Vasilyan et al. 2013: 306, fig. 3b-e) and also from that of Aviturus execratus in significantly less numerous and larger medullary cavities (see Vasilyan and Böhme 2012: 3, fig. 4a-c). The prominent and wide processus odontoideus of the atlas, the dumbbellshaped centrum of vertebrae, the vertebrae less massive than in Andrias matthewi, the foramen central significantly smaller than in vertebrae of $U$. hypsognatus (Vasilyan et al.
2013: 309, fig. 6e), and the massive, short neural spine, ending in cartilage also refer to a close affinity with A. scheuchzeri (see Estes 1981). When comparing the fossil skeletal elements from Pécs-Danitzpuszta with those of recent giant salamanders, no significant differences can be observed, similar to what was described previously by Westphal (1958) about Andrias scheuchzeri in his study on European Andrias fossils.

\section{Discussion}

A considerable portion of the vertebrate remains at the PécsDanitzpuszta site is reworked from older, Middle MioceneBadenian and Sarmatian s.s. - sediments (Sebe et al. 2015a). The diverse chondrichthyan fauna is typical for the Badenian of Europe. Partially articulated bony fish skeletons (e.g. a yet unidentified species of latids, which fishes primarily live in freshwater) are evidently coeval with the sediment, i.e. late Miocene (Szabó et al. in prep.). The numerous reptilian remains are mostly freshwater or terrestrial forms, but have been identified so far very approximately, at a level not sufficient to assign an age to them. The extraordinarily abundant marine mammal fauna includes predominantly cetaceans (whales and dolphins) and sirenians, in smaller quantities pinnipeds (seals), identified taxa are of Badenian and Sarmatian s.s. age (Kordos 1992; Kazár et al. 2007). Diverse terrestrial mammalian remains include hipparions, proboscideans, rhinocerotids, tapirs, suids and ruminants (bovids, tragulids and cervids). Most of them represent a typical early Pannonian (Vallesian) assemblage, a so-called Hipparion fauna. However, a small sized deinothere (cf. Prodeinotherium bavaricum) refers to redeposition of fossils from older (Badenian and/or Sarmatian) sediments also in the case of terrestrial taxa (Sebe et al. 2015a). Therefore, although the Andrias fossils were found in Upper Miocene (lower Pannonian/lower Tortonian) sands, their Late Miocene age is not unambiguous. This question can be discussed considering the ecological requirements of the taxon and using analogous finds of similar age.

Cryptobranchids occur exclusively in humid areas, with mean annual precipitations exceeding $900 \mathrm{~mm}$ (Böhme et al. 2012). Climatic analysis, based on fossil flora, estimated a mean annual precipitation of $\sim 1000 \mathrm{~mm}$ for the deposition time of the Danitzpuszta sediments (Erdei et al. 2007; Hably and Sebe 2016). Macrofloral remains at Danitzpuszta indicate expressedly thermophilous vegetation, where the prevalence of Lauraceae and other thermophilous elements in the vegetation excludes freezing temperatures (Hably and Sebe 2016). These climatic conditions made the early late Miocene of the southern Pannonian Basin suitable for giant salamanders. 
A further environmental prerequisite for the presence of cryptobranchids is considered to be increased relief due to regional uplift, which produces the necessary habitats, mountain valleys for the giant salamanders (Böhme et al. 2012). Uplift of the Mecsek Mountains during the early late Miocene is unambiguously indicated by the upwards gradually decreasing bedding dip, i.e. syn-tectonic deposition in the sands containing the Andrias bones (Konrád and Sebe 2010). Steep topography was proposed based on the event-like input of coarse clastic sediments-sand and gravel-with redeposited Pannonian littoral mollusks into the open-water calcareous marl succession underlying the sands (Sebe et al. 2015b). Increased relief is shown by vegetation types linked to various elevations from lakeshore to upland (Hably and Sebe 2016). The appearance of the fossil-bearing sands above the carbonate-dominated lacustrine succession itself refers to increased activity of watercourses and to the resulting denudation and clastic input into the lake. Direct evidence for the existence of freshwater habitats, namely swamps is provided by the massive occurrence of Myrica lignitum leaves among the fossil flora. Shoot fragments of Glyptostrobus europaeus, another typical swamp plant, were interpreted as having been transported from a distance into Lake Pannon and thus indicate that freshwater wetlands were present further away on the mainland (Hably and Sebe 2016).

Thus, although their exact age cannot be indisputably identified, based on the listed climatic and topographic arguments the Andrias fossils can be coeval with the host sediments. Moreover, the giant salamanders live in streams, i.e. in high-energy sedimentary environments, so the partially eroded surface of the bones does not necessarily indicate their post-depositional transport. The preservation of bones found at the Pécs-Danitzpuszta site is also comparable to that of in situ Andrias bones from molasse deposits (Vasilyan et al. 2013, fig. 3a and personal communication from Davit Vasilyan). The presence of Andrias in the Mecsek Mountains during the late Miocene would fit into and confirm the view of the early late Miocene palaeogeography as having a relief more rugged and a climate more humid and mild than today.

The nearest sites with Andrias fossils are located along the western margin of the Pannonian Basin (Fig. 1). In the Styrian Basin in Austria, Andrias scheuchzeri vertebrae and a maxilla were found in the lower Upper Miocene (uppermost MN7/8) clay pit of Mataschen, at the foot of the Eastern Alps (Tempfer 2004; Gross et al. 2007). Two other sites (Brunn-Vösendorf and Götzendorf/Sandberg) are located more to the north, in the Vienna Basin (Harzhauser and Tempfer 2004). A vertebra and a humerus were reported from the "Congeria beds" of Brunn-Vösendorf (Papp et al. 1953; Thenius 1954), again next to the Eastern Alps. This site has a late Miocene age as well and is correlated to the middle MN9 zone (Miklas 2002; Tempfer 2004). The third location, Götzendorf/Sandberg, lies just west of the Leitha Mountains and provided a rich herpetofauna, including several bones of both adult and juvenile Andrias scheuchzeri recovered from deposits of a side-branch of the Late Miocene paleo-Danube (Miklas 2002; Harzhauser and Tempfer 2004). The small mammal taxa of the outcrop indicate the upper MN9 zone and chronologically the locality is indirectly dated to $\sim 10 \mathrm{Ma}$ based on the close similarity of the evolutionary stage of the small mammal fauna to that of radiometrically dated faunas in Turkey and Germany (Miklas 2002). All three listed Andrias locations are of early late Miocene age, similarly to the Danitzpuszta sands. They lie next to elevated topography, be it the Alps or the lower Leitha Mountains, like Danitzpuszta lies at the foot of the Mecsek Mountains. Therefore, the Pécs-Danitzpuszta site is a further, fourth locality in the Pannonian Basin where giant salamanders could find their habitats in the late Miocene. The distribution of late Miocene sediments of various ages shows that the Mecsek Mountains formed an island in Lake Pannon from the beginning of the Late Miocene to $\sim(-7)$ Ma (Magyar et al. 1999; Sebe et al. 2015a, b). This island had dimensions of at least $70 \times 15 \mathrm{~km}$ during the early Late Miocene, an extent large enough to develop a well-developed drainage network and to provide habitat (Fig. 8) for the Andrias.

Cryptobranchids (Megalobatrachidae indet.) were mentioned from the Pliocene of SW Hungary, from the sites Csarnóta 2 (Jánossy 1986) and Beremend 26 (Császár and Kordos 2007) in the Villány Hills, $30 \mathrm{~km}$ south of the Mecsek Mts. We investigated these small amphicoelous vertebrae deposited in the collection of the Hungarian Natural History Museum and did not confirm their attribution to the family Cryptobranchydae: neither their shape, nor their small size $(<3 \mathrm{~mm})$ supports the original identification. Therefore, the remains from Pécs-Danitzpuszta are the only giant salamander fossils known from Hungary so far.

\section{Conclusions}

Based on cranial and postcranial bones, giant salamanders were present in the Miocene of the Mecsek Mountains in southern Hungary. The studied fossils are attributed to the species Andrias scheuchzeri.

The fossils of Andrias from Pécs-Danitzpuszta are isolated, incomplete and mostly eroded, suggesting pre-depositional transport. The most frequent bones are the massive dentaries (especially its anterior part), whilst the more vulnerable maxilla, vertebrae and elements of the appendicular skeleton are significantly rare. 


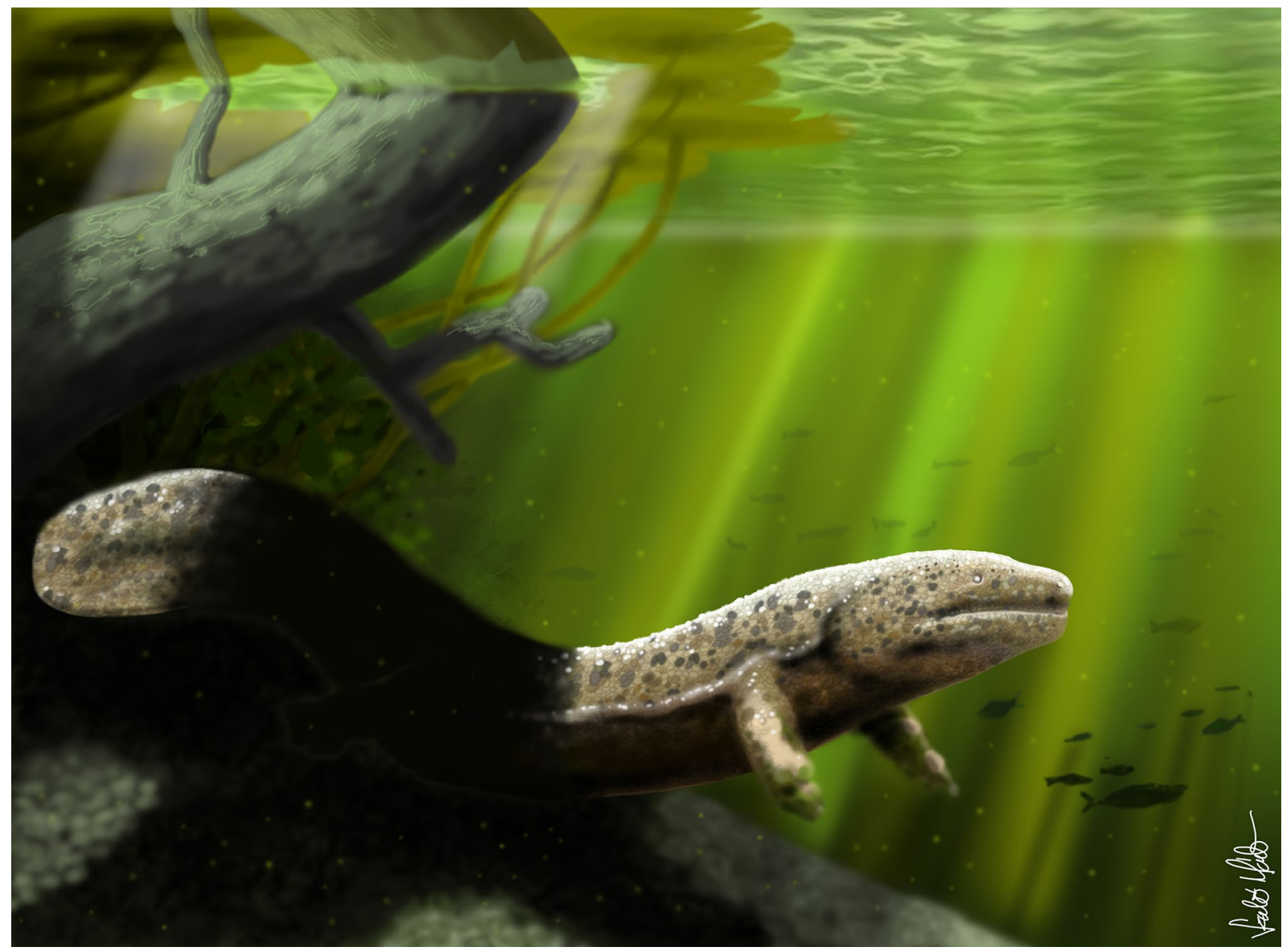

Fig. 8 Reconstruction of the late Miocene freshwater environment of Pécs-Danitzpuszta and the Andrias scheuchzeri (artwork by Márton Szabó, 2019)

Giant salamanders lived on an island within the Central Paratethys in the Middle Miocene or within the brackish Lake Pannon in the Late Miocene. Although their exact age cannot be indisputably identified, the Andrias fossils can be coeval with the Upper Miocene host sediments. Arguments supporting suitable conditions for giant salamanders in the early late Miocene of the southern Pannonian Basin are the mild and humid climate and the presence of freshwater wetlands on the dryland indicated by the fossil flora, the syn-depositional uplift of the mountains providing for a rugged topography and the intense clastic sediment input into Lake Pannon indicative of a fluvial network on the Mecsek Island and of sufficient precipitation. Even if the fossils are reworked from older sediments, their age cannot be older than Badenian (Langhian).

Acknowledgements Open access funding provided by University of Pécs (PTE). Research was supported by the OTKA/NKFIH (Hungarian National Research, Development and Innovation Office) projects PD104937 and 116618, by the University of Pécs Excellence Centre program (20765-3/2018/FEKUTSTRAT), and by the Bolyai
János Research Scholarship of the Hungarian Academy of Sciences to KS. We are grateful for Tamás Henn, the curator of the József Attila City Library and Museum Collection, and László Makádi and Bálint Szappanos, the curators of the Collection of the Mining and Geological Survey of Hungary for helping our work in these collections. We thank all the collectors who gave their fossils to public institutions and also for those who enabled us to study their materials, namely László Kanizsai (Komló), Tamás Németh (Balatonkenese), Ferenc Cserpák (Budapest), Károly and Arnold Kübler (Komló), Tamás Bertalan and László Sövér (Bonyhád), and Árpád Dávid (Debrecen). We acknowledge the consultations with Lilla Hably (Hungarian Natural History Museum) about the environment. We are grateful to the reviewers Davit Vasilyan (Jurassica Museum, Porrentruy, Switzerland), Márton Venczel (Muzeul Ţării Crişurilor, Oradea, Romania), Jörg Fröbisch (Museum für Naturkunde, Berlin, Germany) and Mike Reich (Munich, Germany) Editor-in-Chief of the PalZ for their thorough reviews and constructive comments, which greatly improved the manuscript.

Open Access This article is distributed under the terms of the Creative Commons Attribution 4.0 International License (http://creativeco mmons.org/licenses/by/4.0/), which permits unrestricted use, distribution, and reproduction in any medium, provided you give appropriate credit to the original author(s) and the source, provide a link to the Creative Commons license, and indicate if changes were made. 


\section{References}

Böhme, M., D. Vasilyan, and M. Winklhofer. 2012. Habitat tracking, range dynamics and palaeoclimatic significance of Eurasian giant salamanders (Cryptobranchidae) indications for elevated Central Asian humidity during Cenozoic global warm periods. Palaeogeography, Palaeoclimatology, Palaeoecology 342-343: 64-72. https://doi.org/10.1016/j.palaeo.2012.04.032.

Böttcher, R. 1987. Neue Funde von Andrias scheuchzeri (Cryptobranchidae, Amphibia) aus der süddeutschen Molasse (Miozän). Stuttgarter Beiträge zur Naturkunde (B: Geologie und Paläontologie) 131: 1-38.

Browne, R.K., H. Li, Z. Wang, P. Hime, A. McMillan, M. Wu, and R. Diaz. 2012. The giant salamanders (Cryptobranchidae): Part A. palaeontology, phylogeny, genetics and morphology. Amphibian and Reptile Conservation 5(4): 17-29.

Browne, R.K., H. Li, Z. Wang, S. Okada, P. Hime, A. McMillan, M. Wu, R. Diaz, D. McGinnity and J.T. Briggler. 2013. The giant salamanders (Cryptobranchidae): Part B. Biogeography, ecology and reproduction. Amphibian and Reptile Conservation 5(4): $30-50$.

Cundall, D.J., J. Lorenz-Elwood, and J.D. Grooves. 1987. Assymetric suction feeding in primitiv salamanders. Experientia 43: $1229-1231$.

Császár, G., and L. Kordos. 2007. Beremend, kőfejtő. Alsó- és középsőkréta Nagyharsányi Mészkő Formáció, pliocén gerinces lelőhelyek. [Upper and Middle Cretaceous Nagyharsány Limestone Formation, Pliocene vertebrate localities]. In Öslénytani kirándulások Magyarországon és Erdélyben, eds. J. Pálfy, and P. Pazonyi, 172-179. Budapest: Hantken Press. (in Hungarian).

Dai, Q., Y. Wang, and G. Liang. 2010. Conservation status of Chinese giant salamander (Andrias davidianus). Chengdu: Chengdu Institute of Biology, Chinese Academy of Sciences.

Dunn, E.R. 1922. The sound-projecting apparatus of the salamanders and the phylogeny of the caudata. The American Naturalist 56: 418-427.

Erdei, B., L. Hably, M. Kázmér, T. Utescher, and A. Bruch. 2007. Neogene flora and vegetation development of the Pannonian domain in relation to palaeoclimate and palaeogeography. Palaeogeography, Palaeoclimatology, Palaeoecology 253: 131-156. https://doi. org/10.1016/j.palaeo.2007.03.036.

Estes, R. 1981. Gymnophyona, Caudata. In Handbuch der Paläoherpetologie Part 2, ed. P. Wellnhofer, 1-115. Stuttgart: G. Fischer.

Fitzinger, L.J. 1826. Neue Classification der Reptilien nach ihren natürlichen Verwandtschaften nebst einer Verwandtschafts-Tafel und einem Verzeichnisse der Reptilien-Sammlung des K. K. zoologischen Museum's zu Wien. Wien: J.G. Heubner.

Francis, E.T.B. 1934. Anatomy of the salamander. Oxford: Clarendon Press.

Gardner, J.D., Z. Roček, T. Přykril, J.G. Eaton, R.W. Blob, and J.T. Sankey. 2010. Comparative morphology of the ilium of anurans and urodeles (Lissamphibia) and a re-assessment of the anuran affinities of Nezpercius dodsoni Blob et al. 2001. Journal of Vertebrate Paleontology 30: 1684-1696. https://doi.org/10.1080/02724 634.2010.521605.

Gross, M., I. Fritz, W.E. Piller, A. Soliman, M. Harzhauser, B. Hubmann, B. Moser, R. Scholger, T.C. Suttner, and H.-P. Bojar. 2007. The Neogene of the Styrian Basin - Guide to excursions. Joannea Geologie und Paläontologie 9: 117-193.

Hably, L., and K. Sebe. 2016. A late Miocene thermophilous flora from Pécs-Danitzpuszta, Mecsek Mts., Hungary. Neues Jahrbuch für Geologie und Paläontologie 279(3): 261-271. https:// doi.org/10.1127/njgpa/2016/0554.

Haeckel, E.H.P.A. 1866. Generelle Morphologie der Organismen. 2. Berlin: G. Reimer.
Harzhauser, M., and P.M. Tempfer. 2004. Late Pannonian Wetland Ecology of the Vienna Basin based on Molluscs and Lower Vertebrate Assemblages (Late Miocene, MN 9, Austria). Courier Forschungsinstitut Senckenberg 246: 55-68.

Holl, F. 1831. Handbuch der Petrefaktenkunde. Dresden.

Jánossy, D. 1986. Pleistocene vertebrate faunas of Hungary. Budapest: Akadémiai Kiadó.

Kazár, E., L. Kordos, and M. Szónoky. 2007. Danitz-puszta. In Óslénytani kirándulások Magyarországon és Erdélyben [Palaeontological excursions in Hungary and Transylvania], eds. J. Pálfy and P. Pazonyi, 131-132. Budapest: Hantken Kiadó. (in Hungarian).

Kleb, B. 1973. Geologie des Pannons im Mecsek. Annals of the Hungarian Geological Institute 53(3): 750-943.

Konrád, G., and K. Sebe. 2010. Fiatal tektonikai jelenségek új észlelései a Nyugat-Mecsekben és környezetében [New Records of Young Tectonic Phenomena in the Western Mecsek Mts. and their Surroundings]. Földtani Közlöny 140(2): 445-468. (in Hungarian).

Konrád, G., L. Kordos, and K. Sebe. 2010. Danitz-pusztai homokbánya, Pécs, Mecsek. Őslényvadászat a Pannon-tó peremén. [Danitz-puszta sandpit, Pécs, Mecsek Mts. Fossil hunting along the shores of Lake Pannon]. In A múlt ösvényein [On trails of the past], ed. J. Haas, 160-164, Budapest: Hungarian Geological Society. (in Hungarian).

Kordos, L. 1992. Magyarország harmad- és negyedidôszaki emlösfaunájának fejlődése és biokronológiája. [Evolution and biochronology of the Tertiary and Quaternary mammal fauna of Hungary]. DSc thesis, 1-103. Budapest: Hungarian Academy of Sciences. (in Hungarian).

Linnaeus, C. 1758. Systema natura per regna tria natura, secundum classes, ordines, genera, species, cum characteribus, differentiis, synonymis, locis. Tomus I. Editio decima, reformata. Stockholm [=Holmiae]: Laurentii Salvii.

Magyar, I., and D.H. Geary. 2012. Biostratigraphy in a Late Neogene Caspian-type lacustrine basin: Lake Pannon, Hungary. In Lacustrine sandstone reservoirs and hydrocarbon systems, eds. O.W. Baganz, Y. Bartov, K.M. Bohács, and D. Nummedal. AAPG Memoir 95: 255-264.

Magyar, I., D.H. Geary, and P. Müller. 1999. Paleogeographic evolution of the Late Miocene Lake Pannon in Central Europe. Palaeogeography, Palaeoclimatology, Palaeoecology 147(3): 151-167. https ://doi.org/10.1016/S0031-0182(98)00155-2.

Meszoely, C. 1966. North American fossil Cryptabranchid Salamanders. American Midland Naturalist 75(2): 495-515.

Miklas, P.M. 2002. Die Amphibienfauna (Amphibia: Caudata, Anura) der obermiozänen Fundstelle Götzendorf an der Leitha (südliches Wiener Becken, Niederösterreich). Annalen des Naturhistorischen Museums in Wien 103A: 161-211.

Naylor, B.G. 1981. 1981: Cryptobranchyd Salamanders from the Paleocene and Miocene of Saskatchewan. Copeia 1: 76-86.

Nickerson, M.A., K.L. Krysko, and R.D. Owen. 2003. Habitat differences affecting age class distributions of the hellbender, Cryptobranchus alleganiensis. Southwestern Naturalists 2(4): 619-629.

Okada, S., T. Utsunomiya, T. Okada, Z.I. Felix, and I. Fumihiko. 2008. Characteristics of Japanese giant salamander (Andrias japonicus) populations in two tributary streams in Hiroshima Prefecture, western Hon-shu Japan. Herpetological Conservation and Biology 3(2): 192-202.

Papp, A., E. Thenius, W. Berger, and E. Weinfurter. 1953. Vösendorfein Lebensbild aus dem Pannon des Wiener Beckens. Mitteilungen der Geologischen Gesellschaft in Wien 46(Sonderband): 1-109. Wien, 1954.

Ratnikov, V.Y., and S.N. Litvinchuk. 2009. Atlantal vertebrae of tailed amphibians of Russia and adjacent countries. Russian Journal of Herpetology 16(1): 57-68. 
Reese, A.M. 1906. Anatomy of Cryptobranchus allegheniensis. The American Naturalist 40(472): 287-326.

Roček, Z. 1997. A Review of the fossil caudate of Europe. Abhandlungen und Berichte für Naturkunde 17: 51-56.

Scopoli, G.A. 1777. Introductio ad Historiam Naturalem, Sistens Genera Lapidum, Plantarum et Animalium Hactenus Detecta, Caracteribus Essentialibus Donata, in Tribus Divisa, Subinde ad Leges Naturae. Prague: W. Gerle.

Sebe, K., G. Csillag, A. Dulai, M. Gasparik, I. Magyar, I. Selmeczi, M. Szabó, O. Sztanó, and A. Szuromi-Korecz. 2015a. Neogene stratigraphy in the Mecsek region. In Neogene of the Paratethyan Region [6th Workshop on the Neogene of Central and SouthEastern Europe. An RCMNS Interim Colloquium. Programme, Abstracts, Field Trip Guidebook. 2015.05.31-06.03, Orfü], eds. I.-R. Bartha, Á. Kriván, I. Magyar, and K. Sebe, 102-124. Budapest: Hungarian Geological Society.

Sebe, K., I. Magyar, G. Csillag, and O. Sztanó. 2015b. A mecseki pannóniai üledékek rétegtana: új adatok, eredmények és kérdések. [Stratigraphy of Upper Miocene (Pannonian) sediments in the Mecsek region: new data, results and questions]. In Tisia Konferencia. Pécs, 27-28. February 2015, eds. V. Dályay, and M. Sámson, 72-76. Pécs: Hungarian Geological Society.

Szabó, M., L. Kocsis, and K. Sebe. in prep. A diverse fish assemblage (Chondrichthyes and Osteichthyes) from the Pécs-Danitzpuszta sand pit (Mecsek Mts., Hungary). Földtani Közlöny. Bulletin of the Hungarian Geological Society.
Tempfer, M.A. 2004. Andrias scheuchzeri (Caudata: Cryptobranchidae) aus der obermiozänen (MN7/8) Fundstelle Mataschen/Steiermark. Joannea Geologie und Paläontologie 5: 257-268.

Thenius, E. 1954. Über das Vorkommen von Riesensalamandern (Cryptobranchidae, Amphibia) im Unterpliozän (Pannon) des Wiener Beckens. Paläontologische Zeitschrift 28(3/4): 172-177.

Tschudi, J.J. von. 1837. Über den Homo diluvii testis, Andrias scheuchzeri. Neues Jahrbuch für Mineralogie, Geognosie, Geologie und Petrefakten-Kunde 5: 545-547.

Vasilyan, D., and M. Böhme. 2012. Pronounced peramorposis in Lissamphibians-Aviturus exsecratus (Urodela, Cryptobarnchidae) from the Paleocene-Eocene Thermal Maximum of Mongolia. PLoS One 7(9): e40665. https://doi.org/10.1371/journ al.pone.0040665.

Vasilyan, D., M. Böhme, V.M. Chkhikvadze, YuM Semenov, and W.G. Joyce. 2013. A new giant salamander (Urodela, Pancryptobrancha) from the Miocene of Eastern Europe (Grytsiv, Ukraine). Journal of Vertebrate Paleontology 33(2): 301-318. https://doi. org/10.1080/02724634.2013.722151.

Westphal, F. 1958. Die tertiären und rezenten eurasiatischen Riesensalamander (Genus Andrias, Urodela, Amphibia). Palaeontographica (A: Paläozoologie, Stratigraphie) 110: 20-92.

Westphal, F. 1970. Neue Riesensalamander-Funde (Andrias, Amphibia) aus der oberen Süßwassermolasse von Wartenberg in Bayern. Mitteilungen der Bayerischen Staatssammlung für Paläontologie und Historische Geologie 10: 253-260. 